\section{Comparison of Mulches for Fresh-market Basil Production}

Jeanine M. Davis

Department of Horticultural Science, North Carolina State University, Mountain Horticultural Crops Research and Extension Center, 2016 Fanning Bridge Road, Fletcher, NC 28732

Additional index words. Ocimum basilicum, sweet basil, bush basil, polyethylene, straw, hardwood bark, pine bark

\begin{abstract}
Using various mulches for small-scale, commercial basil (Ocimum basilicum L.) production was examined. Sweet basil and bush basil, on raised beds with drip irrigation, were grown on bare ground or mulched with black polyethylene, wheat straw, hardwood bark, or mixed wood chips. Bacterial soft rot (Erwinia spp.) was highest for both basils grown with wheat straw and for sweet basil grown on bare ground or with back polyethylene mulch. Both basils grown with hardwood and pine bark mulches had few soft ret symptoms. All mulches provided acceptable weed control. Yields throughout the growing season were highest with black polyethylene mulch and lowest with hardwood and pine bark mulches.
\end{abstract}

Ricotta and Masiunas (1991) indicated that black polyethylene mulch improved basil yields. Black polyethylene, however, is costly to use and disposal is difficult. Recent efforts to reduce organic materials in sanitary landfills have resulted in readily available, lowcost, fresh, organic mulches. Organic mulches may be more costly to apply than black polyethylene but do not need to be removed and can be incorporated into the soil. My objective was to evaluate mulches for small-scale, fresh-market basil production.

Two basils and six mulch treatments were examined in a factorial experiment in a randomized complete-block design with four replications. Although both taxa are classified as $O$. basilicum, one basil was the common sweet basil that grows to $60-90 \mathrm{~cm}$ high, with $4-$ to 10-cm-long glabrous, ovate leaves. The other basil was a bush basil, 'Green Improved', that grows to $15-25 \mathrm{~cm}$ high, with thickened, glabrous, acute leaves $\approx 2 \mathrm{~cm}$ long. This bush basil closely resembles the description for $O$. basilicum 'Minimum'. Mulch treatments were black polyethylene $(1.5 \mathrm{~m}$ wide $\times 0.04 \mathrm{~mm}$ thick), hardwood bark, pine bark, mixed hardwood and softwood chips, wheat straw, and bare ground. The fresh bark mulches were

Received for publication 21 June 1993. Accepted for publication 1 Nov. 1993, This research was supported in part by the North Carolina Agricultural Research Service, Raleigh; the U.S. Dept. of Agriculture Special Grant P.L. 89-106; and a gift from In-Our-Own Way, Mars Hill, N.C. I gratefully acknowledge materials supplied by Netafim, Valley Stream, N.Y., and technical assistance from Duane Crawley and George Cox. Use of trade names does not imply endorsement of the products named nor criticism of similar ones not named, The cost of publishing this paper was defrayed in part by the payment of page charges. Under postal regulations, this paper therefore must be hereby marked advertisement solely to indicate this fact, from a sawmill, and the fresh mixed wood chips were from a local utility roadside clearing operation. Plots consisted of raised beds $4.6 \mathrm{~m}$ long $\times 1 \mathrm{~m}$ wide and $1.5 \mathrm{~m}$ apart center to center with drip irrigation $(0.5 \mathrm{~mm}$ thick, 46 $\mathrm{cm}$ between emitters) (Typhoon; Netafim Irrigation, Valley Stream, N.Y.). Soil was a Delanco loam (fine loamy, mixed, mesic, Aquic Hapludults) with a $\mathrm{pH}$ of 6.0. Before bedding, $112 \mathrm{~kg} \mathrm{~N}, \mathrm{P}$, and $\mathrm{K} / \mathrm{ha}$, were broadcast-applied to the soil and incorporated. On 14 June 1991 , 5-week-old, greenhouse-grown, basil plants were transplanted to the field. At 24, 35, and 52 days after planting, $22 \mathrm{~kg} \mathrm{~N} / \mathrm{ha}(20 \mathrm{~N}-8.6 \mathrm{P}-$ $16.6 \mathrm{~K}), 18 \mathrm{~kg} \mathrm{~N} / \mathrm{ha}(12 \mathrm{~N}-21 \mathrm{P}-6.6 \mathrm{~K})$, and 20 $\mathrm{kg} \mathrm{N} / \mathrm{ha}\left[\mathrm{Ca}\left(\mathrm{NO}_{3}\right)_{2}\right]$, respectively, were applied through the drip-irrigation system. Soil was irrigated as needed to maintain soil moisture content near field capacity. Plants were grown in double rows with $20 \mathrm{~cm}$ between plants and $30 \mathrm{~cm}$ between rows. Holes were punched in the black polyethylene mulch with a hand-operated bulb planter and organic mulches were applied to a depth of $\approx 8 \mathrm{~cm}$.

Leaves were harvested four times. At each harvest, new leaf growth was cut, leaving several axillary buds on each branch for regrowth. Data are presented on a fresh-weight basis; percent dry weight averaged $13 \%$ for both basils. All data were subjected to analysis of variance and means were separated using the protected least significant difference procedure (MSTAT-C, Michigan State Univ.).

By 15 Aug., $75 \%$ of the sweet basil and $84 \%$ of the bush basil plants grown on wheat straw had symptoms of bacterial soft rot (Erwinia spp.), as did $>50 \%$ of the sweet basil grown on bare ground or with black polyethylene mulch (Table 1). In contrast, both basils grown on hardwood and pine bark mulches had few soft rot symptoms, and bush basil grown on bare ground had no soft rot. This difference in soft rot infection between the two basils on bare ground is the primary cause of the significant basil $\times$ mulch interaction. Soft rot, which was a problem due to extended periods of rain, enters plants primarily through wounds and can be spread by direct contact and in water splashed up from the soil (Agrios, 1978). Thus, fresh-market basil is at high risk of infection because of many wounds inflicted on plants during harvest. Although mulch might reduce the spread of infection by preventing water-borne spores from splashing from soil onto the foliage, soft rot was common in mulched treatments. The indication that certain mulches may reduce the incidence of this disease, however, warrants further study. Keeping weed populations low is an important factor in basil production (Ricotta and Masiunas, 1991), and compared to bare ground, all mulches were effective in controlling weeds, with the best control provided by black polyethylene (Table 1).

At first harvest of both basils, plants treated with black polyethylene mulch obtained the greatest yields (Table 2), probably because of high soil temperatures (Ashworth and Harrison, 1983). For bush basil, however, first-harvest yields with black polyethylene were not different from those obtained with wheat straw. This was unexpected because Ashworth and Harrison (1983) reported soil temperatures under straw were lower than under bark or black polyethylene. At all harvests, yields of both basils were the same or higher with black polyethylene than bare ground. Basil grown on wheat straw had yields similar to those on bare ground at all harvests, whereas plants grown with any wood-based mulch had the lowest yields. Even with high percentages of plants infected with soft rot, total yields for both basils were higher with black polyethylene than bare ground (Table 2). In contrast, even though soft rot infection was minimal, yields from plants grown with hardwood bark or pine bark were lower than those grown on bare ground. Total yields for plants grown with wheat straw or mixed wood chips were

Table 1. Mulch effects on bacterial soft rot (Erwinia spp. $)^{2}$ and weed populations in fresh-market basil.

\begin{tabular}{|c|c|c|c|}
\hline \multirow[b]{2}{*}{ Mulch } & \multicolumn{2}{|c|}{ Plants with soft rot $(\%)$} & \multirow[b]{2}{*}{ Weeds } \\
\hline & Sweet basil & Bush basil & \\
\hline Bare ground & 57.5 & 0.0 & 9.1 \\
\hline Black & & & \\
\hline $\begin{array}{l}\text { polyethylene } \\
\text { Hardwood }\end{array}$ & 61.0 & 31.5 & 1.4 \\
\hline $\begin{array}{l}\text { Hardwood } \\
\text { bark }\end{array}$ & 15.0 & 3.0 & 3.4 \\
\hline Pine bark & 5.0 & 8.8 & 2.8 \\
\hline $\begin{array}{l}\text { Mixed } \\
\text { wood chips }\end{array}$ & 49.0 & 11.8 & 4.1 \\
\hline Wheat straw & 75.3 & 84.0 & 4.0 \\
\hline $\begin{array}{l}\text { LSD }_{0,01} \\
\text { Sionificance }\end{array}$ & 31.3 & 31.3 & 1.8 \\
\hline $\begin{array}{l}\text { Significance } \\
\text { Basil }\end{array}$ & & ${ }^{*} *$ & NS \\
\hline Mulch & & ** & $* *$ \\
\hline $\begin{array}{l}\text { Basil } \times \\
\text { mulch }\end{array}$ & & $* *$ & NS \\
\hline
\end{tabular}

${ }^{2}$ Soft rot incidence was evaluated on 15 Aug.

${ }^{\gamma}$ Means are for main effects over both basils. Weeds were rated on 10 Sept. on a subjective scale $(0=$ no weeds; $10=$ heavy weed population).

${ }_{\mathrm{Ns}, "}$ Nonsignificant or significant at $P \leq 0.01$, respectively. 


\section{CropProduction}

Table 2. Mulch effects on fresh-market basil yields per unit bed length. ${ }^{2}$

\begin{tabular}{|c|c|c|c|c|c|c|c|c|c|c|}
\hline \multirow[b]{4}{*}{ Mulch } & \multicolumn{10}{|c|}{ Basil yield $\left(\mathrm{g} \cdot \mathrm{m}^{-1}\right)$} \\
\hline & \multicolumn{5}{|c|}{ Sweet } & \multicolumn{5}{|c|}{ Bush } \\
\hline & \multicolumn{4}{|c|}{ Harvest date } & \multirow{2}{*}{$\begin{array}{l}\text { Total } \\
\text { yield }\end{array}$} & \multicolumn{4}{|c|}{ Harvest date } & \multirow{2}{*}{$\begin{array}{l}\text { Total } \\
\text { yield }\end{array}$} \\
\hline & 19 July & 2 Aug. & 21 Aug. & 11 Sept. & & 19 July & 2 Aug. & 21 Aug. & 11 Sept. & \\
\hline Bare ground & 632 & 4450 & 549 & 5067 & 2460 & 616 & 284 & 839 & 721 & 2138 \\
\hline Black polyethylene & 1055 & 566 & 782 & 621 & 3026 & 885 & 396 & 929 & 817 & 3024 \\
\hline Hardwood bark & 170 & 218 & 398 & 460 & 1739 & 238 & 238 & 596 & 666 & 1245 \\
\hline Pine bark & 222 & 282 & 386 & 502 & 151 & 210 & 539 & 660 & 1552 & 1391 \\
\hline Mixed wood chips & 429 & 344 & 479 & 443 & 1996 & 410 & 292 & 707 & 587 & 1695 \\
\hline Wheat straw & 769 & 350 & 520 & 542 & 2675 & 746 & 348 & 815 & 763 & 2182 \\
\hline $\operatorname{LSD}_{0.01}{ }^{y}$ & \multicolumn{4}{|c|}{230} & & \multicolumn{4}{|c|}{185} & \\
\hline $\operatorname{LSD}_{0.01}{ }^{x}$ & & & & & 554 & & & & & 390 \\
\hline \multicolumn{11}{|l|}{ Significance } \\
\hline Mulch & \multicolumn{5}{|c|}{$* *$} & \multicolumn{4}{|c|}{$* *$} & \\
\hline Harvest date & \multicolumn{5}{|c|}{$* *$} & \multicolumn{4}{|c|}{$* *$} & \\
\hline Mulch $\times$ harvest date & \multicolumn{5}{|c|}{$* *$} & \multicolumn{4}{|c|}{ ** } & \\
\hline
\end{tabular}

${ }^{2}$ To provide an indication of the differences in yields obtained with the two basils, yields are presented by basil type. Basil type was significant at $P \leq 0.01$ for all but the first harvest; basil type $\times$ mulch was significant at $P \leq 0.05$ for two harvest dates (data not shown).

${ }^{y}$ For individual harvest dates.

"For total yield.

"** Significant at $P \leq 0.01$.

not different from those on bare ground. For both basils at every harvest date, the highest yields were obtained with black polyethylene mulch. The significant mulch $\times$ harvest date interactions were caused by the varying yield response to the other five treatments at each harvest date.

Overall, highest yields and best weed control were obtained with basil grown on black polyethylene mulch; although for sweet basil, yields were not significantly different from those obtained with straw mulch. All mulches provided acceptable weed control. Bacterial soft rot was highest in the wheat straw treatment. Using fresh wood mulches resulted in the lowest yields, although incidence of bacterial soft rot was lowest with hardwood bark and pine bark.

\section{Literature Cited}

Agrios, G.N. 1978, Plant diseases caused by bacteria, p. 435-510. In: Plant pathology, second ed. Academic, New York.

Ashworth, S. and H. Harrison. 1983. Evaluation of mulches for use in the home garden. HortScience 18:180-182,

Ricotta, J.A. and J.B. Masiunas. 1991. The effects of black plastic mulch and weed control strategies on herb yield. HortScience 26:539-541. 